\title{
Influence of sett size and spacing on yield and multiplication ratio of ginger (Zingiber officinale Rosc.)
}

\author{
E. T. BLAY, E. Y.DANQUAH \& G. ANIM-KWAPONG \\ Department of Crop Science, University of Ghana, P. O. Box 44, Legon, Ghana
}

\section{SUMMARY}

Four sett sizes $(1,2,5$, and $10 \mathrm{~g})$ of ginger (Zingiber officinale Rosc.) and three spacings $(12 \mathrm{~cm} \times 12 \mathrm{~cm}, 15$ $\mathrm{cm} \times 15 \mathrm{~cm}$, and $15 \mathrm{~cm} \times 23 \mathrm{~cm}$ ) were studied for their effect on sprouting, vegetative growth, yield, and multiplication ratio. Percent sprouting in moist sawdust under greenhouse conditions was highest for the $10 \mathrm{~g}$ sett class and decreased with reduction in sett size. The largest and the smallest sett sizes had 100 and 75 per cent sprouting, respectively. There was a direct relationship between sett size planted and both vegetative growth and rhizome yield. The contrary was observed in sett size to rhizome ratio (multiplication ratio). The smallest sett size yielded a multiplication ratio of 9.85 compared to 4.78 for the largest sett size. Of the three spacing regimens investigated, the wider spacings produced higher vegetative growth as well as rhizome yield per plant. However, rhizome yield/ha was adversely affected by wider spacing. The highest yield of 29.69 t/ha was produced from the largest sett size $(10 \mathrm{~g})$ planted at the closest spacing of 12 $\mathrm{cm} \times 12 \mathrm{~cm}$. The combination of smallest sett size and widest spacing produced the lowest rhizome yield of 3.37 t/ha.

Original scientific paper. Received 4 Feb 98 ; revised 23 Sep 98.

\section{Introduction}

Ginger (Zingiber officinale Rosc.) was one of the earliest oriental spices known to Europe and is still in high demand (Purseglove, 1972). The dried rhizome, which may be scrapped or peeled before
RÉSUMÉ

Blay, E. T., Danquah, E. Y.\& ANM-KWAPONG, G.: L'influence de la dimension d'échantillon et de l'espacement sur le rendement et la proportion de multiplication de gingembre (Zingiber officinale Rosc.). Quatre dimensions d'échantillon $(1,2,5$, et $10 \mathrm{~g})$ de gingembre et trois espacements $(12 \mathrm{~cm} \times 12 \mathrm{~cm}, 15 \mathrm{~cm} \times 15 \mathrm{~cm}$ et $15 \mathrm{~cm} \times$ $23 \mathrm{~cm}$ ) étaient étudiés pour leur effet sur la pousse, la croissance végétative, le rendement et la proportion de multiplication. Le pourcentage de la pousse dans la sciure de bois humide sous les conditions de serre, était le plus élevé pour la classe d'échantillon de $10 \mathrm{~g}$ et diminuait avec la réduction en dimension d'échantillon. La plus grande et la plus petite dimensions d'échantillon avaient respectivement 100 et 75 pour cent de pousse. Il y avait un rapport direct entre la dimension d'échantillon planté et non seulement la croissance végétative mais aussi le rendement de rhizome. Le contraire était observé dans la proportion (proportion de multiplication) de dimension d'échantillon contre le rendement de rhizome. Le plus petit d'échantillon rendait une proportion multipicative de 9.85 comparée à 4.78 pour la plus grande dimension d'échantillon. Sur les trois échantillons d'espacement étudiés, les espacements plus étendus produisaient une croissance végétative plus élevée ainsi qu'un rendement de rhizome par plante. Cependant le rendement de thizome/ha était défavorablement influé par l'espacement plus étendu. Le rendement le plus élevé de $29.69 \mathrm{t} / \mathrm{ha}$ était obtenu d'échantillons les plus grands $(10 \mathrm{~g})$ plantés à l'espacement le plus proche de $12 \mathrm{~cm} \times 12 \mathrm{~cm}$. La combinaison de dimension d'échantillon le plus petit avec l'espacement le plus étendu produisaient le plus faible rendement de rhizome de $3.37 \mathrm{t} / \mathrm{ha}$.

drying, constitute the spice, and is esteemed for its flavour, pungency, and aroma. In Europe, it is widely use for culinary purposes in gingerbread, biscuits, cakes, puddings, soups and pickles, and also to produce ginger beer, ginger ale, and ginger 
wine. The cultivars of ginger grown in West Africa are recognized worldwide for their high quality (Kochhar, 1986). In Ghana, the current production level of the crop is low, and it is limited to backyard gardens or grown as a minor component of a mixed cropped food farm (Osei Kwakye, 1970). The high demand for the crop on the international market makes it a potential candidate for promotion as a non-traditional export crop for Ghana. However, the availability of adequate quantities of planting material remains the most serious factor limiting the expansion of the area under cultivation.

Setts used for propagation are pieces of the rhizome, which is also the economic product. It is, therefore, desirable to develop an efficient strategy for optimizing the generation and use of the planting material. The minisett/microsett technology could offer an appropriate and sustainable means of addressing the scarcity of planting material. Several workers have reported a direct relationship between sett size and rhizome yield. However, most of these reports did not make any reference to the multiplication ratio.

Timpo (1982) investigated the effect of 3-sett sizes on the performance of two cultivars of ginger. The sett sizes used varied from 20.16 to $44.36 \mathrm{~g}$ for one variety, and 13.86 to $38.43 \mathrm{~g}$ for the other. In both instances, the largest sett sizes gave the highest yield. Sengupta et al. (1986) compared sett sizes ranging from 10 to $40 \mathrm{~g}$ and plants generated from $40 \mathrm{~g}$ sett sizes performed best. Similar results have been reported by Ahmed et al. (1988), Okuowulu (1988), Korla, Rattan \& Dohhhro (1989), and Roy \& Wamanan (1990). Okuowulu (1988), however, stated that even though flowering and yield improved significantly when sett size was increased from 5 to $40 \mathrm{~g}$, the 'sett-harvest-to-multiplication ratio' was adversely affected. Arene, Orkwor \& Okuowulu (1986) reported significant influence of both sett size and spacing on yield. The $20 \mathrm{-g}$ setts planted at $20 \mathrm{~cm}$ $\times 20 \mathrm{~cm}$ spacing had the highest input-output ratio.

This study was therefore designed to determine the minimum sett size and optimum spacing for multiplying and generating planting material efficiently.

\section{Materials and methods}

Two experiments were carried out. The first was conducted in the greenhouse to determine the effect of sett size on sprouting by using 1, 2, 5, and $10 \mathrm{~g}$ rhizome pieces each having at least one bud. The randomized complete block design was used. Each block was represented by a wooden box $30 \mathrm{~cm} \times 75 \mathrm{~cm} \times 10 \mathrm{~cm}$ filled with moist sawdust. Single rows of 20 setts of each weight were randomly arranged in each box. Each treatment was replicated three times. The setts were moistened by sprinkling tap water on the sawdust. when necessary. The number of setts in each class which sprouted rotted or otherwise failed to sprout was recorded 4 weeks after planting (4WAP).

The second experiment was designed to find the best spacing for field planting of the different classes. It was conducted at the research farm of the University of Ghana, Legon, from February to November 1995. The soils on the farm belong to the Nyibenya-Hatscho series, and are free draining and inherently low in fertility (Brammer, 1962). The cultivar and sett sizes investigated were the same as in the glasshouse study. The setts were pre-sprouted before transplanting to the field to ensure uniform field stand. Three intra and inter row spacing combinations were investigated as follows: $12 \mathrm{~cm} \times 12 \mathrm{~cm}(\mathrm{~S} 1), 15 \mathrm{~cm}$ $\times 15 \mathrm{~cm}$ (S2), and $15 \mathrm{~cm} \times 23 \mathrm{~cm}$ (S3) on the flat. Ten grams of NPK 15:15:15 compound fertilizer were applied to each planting hole at the time of field transplanting. One month after planting, a top dressing of sulphate of ammonia at the rate of $50 \mathrm{~kg} / \mathrm{ha}$ was applied and repeated 3 months later. Weeding, mulching, and supplementary irrigation were carried out as necessary. To remove the border effects on spacing, the following records were taken on only nonborder plants:

1. Plant height measured at monthly intervals from day of field planting to harvesting.

2. Leaf area per plant measured by the tracing 
method. The total area occupied by the outlines of the leaf together with measurement of the leaf area clasping the pseudosperm.

3. Leaf area index calculated from the total leaf area of sample plants/ground space occupied.

4. Dry matter production computed from the oven-dry weight of all aerial plant parts of sample plants.

5. Number of shoots per plant determined by counting the number of tillers or clumps/ plant at harvest.

6. Yield of fresh rhizome per hectare determined from the yield per plant and plant population per hectare for the different spacings.

7. Harvest index calculated from the ratio of economic yield to biological yield.

8. Multiplication ratio computed from the ratio of the mean yield of rhizome per plant to the sett weight for the different sizes.

9. Percentage sprouting recorded 4 weeks after planting.

For all records, six randomly selected nonborder plants were used and the average of the measured values was determined.

\section{Results and discussion}

Effect of sett weight on sprouting in the nursery Table 1 shows the percentage sprouted, unsprouted, and rotten setts for the different sett sizes. Sprouting percentage varied directly with sett size. The smallest sett $(1 \mathrm{~g})$, which had significantly lowest $(P=0.05)$ sprouting per- centage, however, recorded 75 per cent sprouting. Percent unsprouted and rotten setts were inversely related to sett size. The smallest sett had the significantly highest $(P=0.05)$ nonsprouting percentage of 17.5 , followed by the $2-\mathrm{g}$ setts which had 8.5 per cent non-sprouting. There was no significant difference $(P=0.05)$ between the 3- and 4-g setts for percentage unrotted setts which, however, failed to sprout. The incidence of rotten setts was not significantly affected by sett size. Although the larger food reserves expected from the bigger setts seemed to positively influence sprouting, the $1 \mathrm{-g}$ sett size had an acceptable sprouting. Hence, where pre-sprouting in sawdust or other media could be practised, it may be practicable to adopt such sett size for multiplication if planting material is limited.

\section{Effect of sett size on vegetative growth and rhizome yield}

The leaf area/plant, leaf area index (LAI), number of tillers per plant, above-ground dry matter/plant, and rhizome yield all significantly $(P=0.05)$ increased with increase in sett size. A similar observation was made by Sengupta $e t$ al. (1986) and Korla, Rattan \& Dohhhro (1989). The initial gain in sprouting efficiency and increase in sett size were sustained through subsequent vegetative growth. Both the number of leaves per clump and plant height increment over the growing period were positively influenced by increasing sett size. The number of leaves (shoots)/clump directly affect the leaf area index.

TABle 1

Effect of Sett Weight on Some Parameters of Ginger

\begin{tabular}{|c|c|c|c|c|c|c|c|c|c|}
\hline Sett weight & $\begin{array}{c}\% \\
\text { sprouted }\end{array}$ & $\begin{array}{c}\% \\
\text { unsprouted }\end{array}$ & $\begin{array}{c}\text { Mean dry } \\
\text { matter } \\
w t / p t\end{array}$ & $\begin{array}{l}\text { Mean leaf } \\
\text { area/pt } \\
\text { (g) }\end{array}$ & $\begin{array}{l}\text { Mean leaf } \\
\text { area index }\end{array}$ & $\begin{array}{c}\text { Mean } \\
\text { no. of } \\
\text { shoots } / p t\end{array}$ & $\begin{array}{c}\text { Mean } \\
\text { yield/pt } \\
(g)\end{array}$ & $\begin{array}{c}\text { Mean } \\
\text { yield/ } \\
\text { t/ha }\end{array}$ & $\begin{array}{c}\text { Mean } \\
\text { multiplication } \\
\text { ratio }\end{array}$ \\
\hline $1.0 \mathrm{~g}=\mathrm{P} 2$ & 75.0 & 17.5 & 11.40 & 1876.70 & 1.90 & 4.0 & 9.86 & 4.42 & 9.85 \\
\hline $2.0 \mathrm{~g}=\mathrm{P} 2$ & 86.25 & 8.75 & 17.65 & 2571.40 & 2.07 & 6.0 & 18.24 & 8.19 & 9.14 \\
\hline $5.0 \mathrm{~g}=\mathrm{P} 3$ & 98.75 & 1.25 & 30.04 & 5833.50 & 3.38 & 8.0 & 34.67 & 16.40 & 6.80 \\
\hline $10.0 \mathrm{~g}=\mathrm{P} 4$ & 100.0 & 0 & 37.69 & 9143.96 & 4.94. & 11.0 & 47.70 & 22.06 & 4.78 \\
\hline$L S D=5 \%$ & 1.89 & 1.05 & 4.56 & $1229.7]$ & 0.17 & 0.14 & 4.05 & 2.61 & 0.60 \\
\hline
\end{tabular}




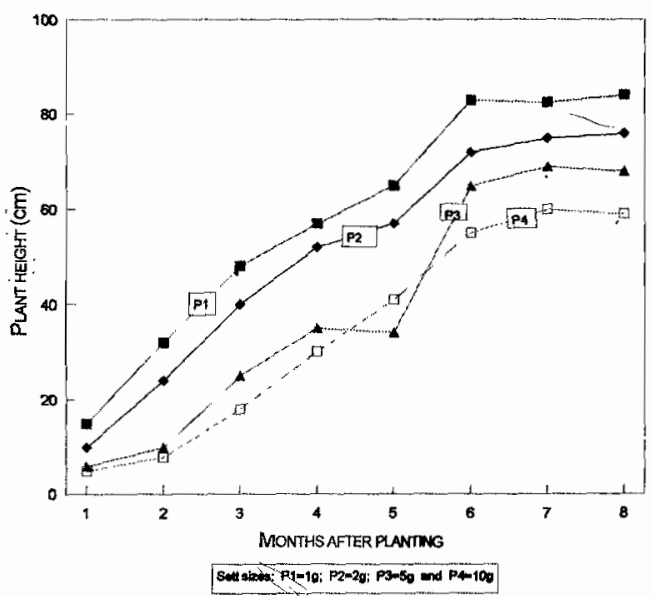

Fig. 1. Changes in plant height during the growth period for plants raised from different sett sizes.

LAI plays a significant role in final yield by improving light interception and photosynthetic efficiency.

Fig. 1 shows changes in plant height during the growth period for plants raised from different sett sizes. All of the plants showed positive increase in height and reached their maximum between the 6 th and 7 th months. The initial growth was slow and lasted for 2 months. From the 3rd to the 6th months, all irrespective of class grew relatively rapidly. Between the 7 th and 8 th months, growth stabilized, showing that the growth pattern was unaffected by sett size.

Anderson (1991), similarly, identified three phases in ginger. The first phase lasted 35-45 days, and was characterized by root and shoot development; the next 150 days showed rapid shoot and leaf growth; and during the last 90 days, both shoot and leaf growth ceased, but rhizome development was accelerated. From the nature of the growth pattern, it is recommended that any agronomic intervention aimed at increasing vegetative growth and yield of ginger should be done within the 3 rd and 6 th months.

Increasing the sett weight from 1 to $10 \mathrm{~g}$ resulted in over five fold increase in rhizome fresh weight from 4.4 to 22.06 tha (Table 1). Sengupta et al.
(1986) also showed that the largest ginger rhizome sett planted had the highest plant weight, number of leaves per clump (shopts), and rhizome yield. Increase in yield was from 33 to 80 per cent for 10 to $40 \mathrm{~g}$ rhizome setts. The yield increase reported. by Sengupta et al. (1986) are lower than those in this study. This may imply that although yield is enhanced by increasing sett weight, the relative gain may decrease beyond a critical threshold sett size. The results for this study showed that both rhizome sizes and total yield depended upon the sett size planted. While the 1- and 2-g setts produced smaller-sized rhizomes, the 5- and 10-g setts produced relatively larger-sized rhizomes. Okibo \& Ibe (1973) reported that in the minisett and microsett technology in yam, the sett size planted determines the sprouting, subsequent vegetative growth, and ultimately the sizes of seed yam produced. In a similar study, Timpo (1982), investigating sett sizes varying from 5 to $9 \mathrm{~cm}$ in ginger, also recorded the highest number of shoots per plant and rhizome yield from the largest sett and vice versa. As reported by Roy \& Wamanan (1990), the yield of rhizomes in ginger is correlated with shoot height, leaves, and tillers per clump of shoots which in turn depend on sett size.

\section{Multiplication ratio}

The multiplication ratio is a critical parameter when considering the generation of planting material, especially in asexually propagated material. This has been the basis for the development of the minisett and microsett technology in yam propagation. The result of the experiment seems to indicate an inverse relationship between sett weight and multiplication ratio (Table 1). The 1-g setts had a multiplication ratio of 9.85 , which was significantly $(P=0.05)$ higher than those of the other sett classes, and the largest sett had the lowest multiplication ratio of 4.78. This may imply that where planting material is limiting, better returns may be derived from planting smaller rather than larger setts. This may be positively exploited for germplasm/seed 
multiplication.

The sett multiplication ratio was also greatly influenced by spacing. Interactions between sett size and spacing had highly significant effects $(P=0.01)$ on sett multiplication ratio. Table 2 shows that the multiplication ratio for all sett sizes was highest for the widest spacing $(15 \mathrm{~cm} \times 23$ observation agrees with the findings of NRCRI $(1982,1983)$. The number of clumps per plant increased with increasing spacing, but did not provide yield compensation for the low seed rate in the wide spacing. The results in Table 3 show that the interaction between the largest planting material $(10 \mathrm{~g})$ and the closest spacing $(12 \mathrm{~cm} \times 12$

TABLE 2

Effect of Spacing on Ginger Yield, Dry Matter Weight, Leaf Area, Leaf Area Index, and Number of Shoots/Plant

\begin{tabular}{lccccccc}
\hline $\begin{array}{c}\text { Spacing } \\
(\mathrm{cm} \times \mathrm{cm})\end{array}$ & $\begin{array}{c}\text { Yield } \\
(\mathrm{t} / \mathrm{ha})\end{array}$ & Yield/pt & $\begin{array}{c}\text { Dry matter } \\
\text { weight/pt }\end{array}$ & $\begin{array}{c}\text { Leaf area } \\
\text { index }\end{array}$ & $\begin{array}{c}\text { leaf area/pt } \\
\left(\mathrm{cm}^{2}\right)\end{array}$ & $\begin{array}{c}\text { No. of } \\
\text { shoots/pt }\end{array}$ & $\begin{array}{c}\text { Multiplication } \\
\text { ratio }\end{array}$ \\
\hline $12 \times 12=\mathrm{S} 1$ & 17.19 & 24.76 & 21.49 & 4.38 & 4108.08 & 7.0 & 6.54 \\
$15 \times 15=\mathrm{S} 2$ & 12.37 & 27.91 & 24.35 & 2.89 & 4883.57 & 7.0 & 7.71 \\
$15 \times 23=\mathrm{S} 3$ & 8.75 & 30.18 & 26.35 & 1.95 & 5577.55 & 9.0 & 8.68 \\
$\mathrm{LSD}=5 \%$ & 1.98 & 2.88 & 1.24 & 0.05 & 690.85 & 0.18 & .0 .04 \\
\hline
\end{tabular}

$\mathrm{cm})$. This is the spacing recommended by Purseglove (1972). Similar highly significant $(P=0.01)$ interactions were observed for all the vegetative growth and yield parameters studied.

Effect of spacing on leaf area, leaf area index, above-ground dry matter, level of clumping (tillers), and yield

Wider spacing positively influenced leaf area, number of tillers per plant, above-ground dry matter, leaf area index, and rhizome yield per plant. Although the number of clumps per plant significantly increased with spacing, it did not appear to compensate for low seed rate in rhizome yield. Yield per hectare was adversely affected due to higher plant density (Table 2). Holliday (1960) suggested a parabolic relationship between yield and plant population; yield rises to a maximum with increasing plant population, but declines at densities beyond a critical value due to excessive interplant competition for essential growth factors. This may account for the decline in economic and biological yield per plant for closer spacing. Yield per plant, dry matter weight, and leaf area decreased as spacing was reduced from $S 3$ to $S 1$. For all sett sizes, yield per hectare declined with increasing spacing. This $\mathrm{cm}$ ) had the highest mean yield of 29.69 tha, while the combination of smallest sett size (1g) and the widest spacing $(15 \mathrm{~cm} \times 23 \mathrm{~cm})$ had the lowest yield of $3.37 \mathrm{t} / \mathrm{ha}$. It is therefore important that the planting distances are chosen with reference to sett sizes to be planted to optimize yield.

\section{Conclusion}

The sett sizes investigated in this study suggest that within limits, larger setts have better yield potential. Yield per plant increases with wider spacing, but is not reflected in yield per hectare owing to the effect of density. There were highly significant interactions between sett size and spacing for all the parameters studied. It is, therefore, critical that planting distances are chosen, considering the sett size to be planted. From the results of the study, and those by other workers, it is recommended that for better yields in total weight and rhizome size, larger sett weights are desirable. However, where planting material is scarce or limited planting material is to be multiplied, the use of smaller sett sizes with high multiplication ratio is preferable. Again, the study has shown that the microsett technology can be efficiently applied to produce planting material in ginger. 
TABLE 3

Effects of Sett Weight $\times$ Spacing on Ginger Yield, Dry Matter, Leaf Area, Leaf Area Index, and Number of Shoots/Plant

\begin{tabular}{lcccccc}
\hline Treatments & $\begin{array}{c}\text { Mean yield } \\
(t / h a)\end{array}$ & $\begin{array}{c}\text { Mean yield/pt } \\
(\mathrm{g})\end{array}$ & $\begin{array}{c}\text { Mean dry matter } \\
w t / p t(\mathrm{~g})\end{array}$ & $\begin{array}{c}\text { Mean leaf } \\
\text { area/pt }\left(\mathrm{cm}^{2}\right)\end{array}$ & $\begin{array}{c}\text { Mean leaf } \\
\text { index }\end{array}$ & $\begin{array}{c}\text { Mean no. of } \\
\text { shoots/pt }\end{array}$ \\
\hline P1S1 & 7.70 & 5.35 & 9.93 & 1627.77 & 1.22 & 4.33 \\
P1S2 & 10.23 & 4.55 & 11.61 & 1909.82 & 1.34 & 4.33 \\
P1S3 & 11.64 & 3.37 & 12.95 & 2066.82 & 1.78 & 4.66 \\
P2S1 & 14.41 & 10.01 & 13.93 & 2092.52 & 1.99 & 5.33 \\
P2S2 & 18.72 & 8.82 & 17.56 & 2387.90 & 2.21 & 5.33 \\
P2S3 & 21.57 & 6.25 & 21.46 & 3259.59 & 2.71 & 7.00 \\
P3S1 & 34.17 & 23.73 & 28.77 & 4805.52 & 2.88 & 7.33 \\
P3S2 & 34.82 & 15.33 & 30.46 & 5492.20 & 3.03 & 7.33 \\
P3S3 & 35.01 & 10.15 & 30.88 & 7202.76 & 3.14 & 10.33 \\
P4S1 & 42.76 & 29.69 & 31.64 & 7932.21 & 2.64 & 9.33 \\
P4S2 & 47.90 & 21.27 & 39.19 & 9744.33 & 4.78 & 10.33 \\
P4S3 & 52.49 & 15.21 & 42.22 & 9755.33 & 7.16 & 13.33 \\
LSD $=5 \%$ & 5.32 & 9.05 & 7.56 & 1504.56 & 1.72 & 0.42 \\
\hline
\end{tabular}

\section{REFERENCES}

Ahmed, N. V., Rahman, M. M., Hogue, M. M. \& Amzad-Hossain, A. K. M. (1988) Effect of seed size on the yield of ginger. Bangladesh Horti. 16, 50-52.

Anderson, T. (1991) Growth phases of the ginger. In CAB: OC Horticultural Abstract 1992, 062-06057, 7Q. Crop physiology 1992, 018-02536.

Arene, O. B., Orkwor, G. C. \& Okuowulu, P. A. (1986) Ginger research in Nigeria. In Tropical root crops. Proceedings of the Third Triennial Symposium of the International Society for Tropical Crops, $\mathrm{pp}$. 89-93.

Brammer, H. (1962) Soils. In Agriculture and land use in Ghana (ed. J. B. Wills). London, Oxford University Press.

Dei-Tutu, J. \& Risch, E. (1976) Studies on the composition of Ghanaian ginger samples. Ghana Jnl agric. Sci. 9, 225-230.

Holliday, B. (1960) Plant population and crop yield . Field Crop Abstract 13 (3), 159-167.

Kochhar, S. L. (1986) Tropical crops. Mcmillan India Ltd.

Korla, B. N., Rattan, R. S. \& Dohhhro, N. P. (1989) Effect of rhizome size on growth and yield in ginger. Indian Cocoa, Arecanut and Spices J. 13, 47-48.

NRCRI (1982) Annual Report, NRCRI, Umudike,
Nigeria.

NRCRI (1983) Annual Report, NRCRI, Umudike, Nigeria.

Okibo, B. N. \& Ibe, F. (1973) New propagation method. Proc. 3rd Int. Symp. trop. Root Crops, IITA, Ibadan, Nigeria

Okuowulu, P. A. (1988) Effect of seed ginger weight on the flowering and rhizome yield of field grown edible ginger (Zingiber officinale Rosc.) in Nigeria. Trop. Sci. 28, 178-176.

Osei-Kwakye, E. (1970) Market for Ghana's ginger. ITC/ECA Promotion Training Course Report, 26 pp. Geneva, ITC/ECA.

Purseglove, J. W. (1972) Tropical monocotyledons. London and Harlow, Longman's Green.

Sengupta, D. K., Maity, T. K., Som, M. G. \& Bose T. K. (1986) Effect of different rhizome sizes on growth and yield of ginger (Zingiber officinale Rosc.) Indian Agric. 30, 201-204.

Timpo, G. M. (1982) Effect of cultivar and seed on growth and yield of ginger (Zingiber officinale Rosc.). Kumasitech J. agric. Sci. 1, 14-21.

Roy, A. R. \& Wamanan, P. P. (1990) Varietal performance and correlation among growth and yield attributes of ginger (Zingiber officinale Rosc.). Indian Agric. 34, 57-61. 